\title{
Walking the Walk: An Integrated STEM Project for Elementary Teachers
}

\author{
Drs. Sarah J Carrier, Valerie N Faulkner, Laura Bottomley
}

\begin{abstract}
Preparing effective STEM (science, technology, engineering, mathematics) education teachers has become a priority of national economic importance (National Research Council [NRC], 2007) and this goal depends on teachers who understand content and possess effective teaching practices that impact student learning. True integration of STEM will require significant changes in classroom practices, shifting away from traditional instruction, and begin with teacher preparation.
\end{abstract}

The present article originates from an interdisciplinary STEM project within an elementary teacher preparation program that has a stated and explicit STEM focus for undergraduate pre-service elementary teachers, yet this investigation also applies to practicing teachers interested in STEM integration. The investigation aims to blur the rigid boundaries that traditionally separate school subjects. Here we highlight a unified investigation project that spans not only disciplines and courses but also pre-service teachers' (PSTs') mindsets.

\section{Framing of STEM Project}

$\square$ lementary PSTs enrolled in their junior year in mathematics, science, and engineering design courses completed one STEM project that met requirements for each of the three courses. Here we frame the presentation of our project with leading science education and mathematics education organizations' and researchers' recommendations for content knowledge and integration.

\section{Content Knowledge}

The National Research Council (2000) states, "to teach science as portrayed by the standards, teachers must have theoretical and practical knowledge and abilities about science" (p. 28), and the National Council of Teachers of Mathematics (2000) declares, "teachers must know and understand deeply the mathematics they are teaching" (p. 17). While teachers' content knowledge contributes to their effectiveness, teachers must also be able to communicate that knowledge to students.

\section{Integration}

The concept of interdisciplinarity implies the process of blending ideas, methods, and theories from multiple disciplines (Repko, 2012). Fink (2013) encourages faculty at universities to provide students with "significant learning experiences" (p. 7) that truly connect to students' lives and experiences, but recognizes the levels of institutional change in higher education and schools that are necessary to blur the boundaries of discipline-specific silos. In 2009 the National Academy of Engineering (NAE, 2009) outlined practical problem solving relating to real world challenges through engineering that increase depth of learning in science, mathematics and other subjects.

\section{The STEM Project}

We, the science, mathematics, and engineering education professors who teach elementary methods courses simultaneously in our PSTs' junior year, collaborated to develop a truly integrated STEM project to address content and methods for each of our three courses. As 
methods professors, we recognized that we needed to "walk the walk" of true integration by modeling our recommendations with one combined assignment that would meet goals for each course's standards.

Our courses were structured to support PSTs' development working in $\mathrm{K}-2$ classrooms with a focus on K-2 standards. We intentionally chose to focus on physical science content standards because elementary school teachers traditionally avoid not only science in general, but especially physical science (Carrier, Tugurian, \& Thomson, 2013; Tilgner, 1990; Weiss, Banilower, McMahon, \& Smith, 2001). The K-2 physical science content standards focus on forces, motion, and sound energy. Mathematics standards include measurement, number and operations, and shapes.

Engineering design standards emphasize the design and revision processes that overlap with both science practices and mathematical practice standards.

The integrated assignment required PSTs to work in pairs to create a series of investigations asking K-2 grade elementary students in their field placement classrooms to design a labyrinth using Unifix $®$ cubes or similar objects to guide the path of a battery-powered mechanical Hexbug ${ }^{\circledR}$. The project goals were to engage students' integrated thinking as they designed a model that included objectives for science, mathematics, and engineering. The labyrinth path was required to include obstacles for the mechanical bug to encounter and continue in motion, a hill, force the bug's change in motion, and a create a change in sound. The intent was to model physical science concepts of force, motion, and sound to blend with mathematical concepts of measurement, shapes, and operations to encourage problem solving and creative thinking. Further, engineering design steps helped the students plan, create, and adapt the labyrinth path. Here we discuss our struggles as professors in shaping the levels of guidance for our PSTs as they worked to provide young children with opportunities to explore STEM.
There were two sections of classes for a total of 57 PSTs who were assigned to field classrooms in pairs. This partner structure was used throughout the field placements and built PSTs' "critical friends" support (Franzak, 2002, p. 261) by working in the field with a partner. This type of social "critical friend" structure serves as a transition for the PSTs from isolated college student learners to teacher learners who will, as professionals, work on grade level and content area teams.

\section{Integrated Content}

While the PSTs in this study were challenged with the depth and nuances of teaching, situating this project early in PSTs' methods coursework allowed PSTs to begin to address the complexities of teaching and integration of STEM instruction. One PST expressed her adaptation to the integrated STEM project, yet still clearly considering the content areas separately. "The areas I felt stronger about teaching were definitely the math compared to the science because the math is a little bit easier to show and demonstrate, whereas the force and the science was a little bit harder to show because I didn't really see that." The logistics of teaching sometimes overwhelmed PSTs' focus on content and instruction as discussed below.

\section{Instructional design}

One PST explained that because she herself did not have positive memories of science, she was surprised by her students' engagement. Her expectations were challenged because the students' behaviors surpassed what she remembered as a student of science:

I didn't think they would be as interested in it as they ended up being...just because I was never very "sciencey" growing up, I didn't really connect with science lessons maybe because they weren't really investigation focused. 
Many of the PSTs were challenged to identify content along with the learning process with students. Students having fun was their measure of success, but it seemed to come at the cost of conceptual understanding. One PST's comment illustrates this struggle, "They were having a lot of fun with the bug, which was great; I just don't think they quite understood why they were doing it." While we know from studies of the human brain that learning is effective when a classroom culture is positive and engaging (Curran \& Stokes, 2003), PSTs at this stage are in the process of learning the balance of marrying engagement with learning, just as they are learning the balance of integrated STEM content instruction.

Coming into methods courses that promote blending STEM content areas often counters PSTs' 14 years of learning in classrooms with separate subject areas divided by time schedules and the functional design of schools. One PST explained her shift in thinking about STEM integration. "We did science with math with engineering all together...It wasn't as hard as I thought it was gonna be. I thought they would be totally separate but they all roll together really easily."

\section{Discussion}

Integrated STEM instruction is traditionally poorly represented in schools (Venville, Rennie, \& Wallace, 2012). As we asked our PSTs to integrate STEM with younger children, the blurred boundaries challenged the PSTs as much as the children. Having spent many years in schools with subjects presented with separate class periods and mindsets, the PSTs were required to dramatically shift their thinking to prepare children with authentic experiences. Calls for preparing students for the STEM workforce (Bayer, 2010) have been misinterpreted. Many of the PSTs' mentor teachers in field placements, rather than identifying STEM as an acronym, used "STEM" to loosely refer to students' designs (e.g., bridges) without identifying the mathematics, science, or technology that would be part of the bridge design process. According to FeimanNemser (2001) "Promoting student learning through discovery is difficult, perhaps too difficult for a novice, but one unsuccessful experience should not lead a teacher to dismiss the whole approach" (p. 176) and rather can encourage analysis and reflection. Building on these realizations, we outline our own reflections.

\section{Supporting PSTs' Content Knowledge}

While watching the videos of young students and considering the PSTs' reflections, it became clear that comfort level with content affected their implementation of the content goals and objectives. For instance, all of the PSTs know how to measure and are aware that measurement is a content standard for $\mathrm{K}-2$ grades, yet only four PSTs out of 57 focused on measurement as a goal with their students.

Almost all groups chose a number and operations goal to address their mathematics requirement. Length measurement is critical to the work that scientists and engineers do on a regular basis, so creating a measurement component within this assignment seemed not only logical, but critical to successfully integrating math objectives seamlessly into the lesson. In our second iteration the following year, we included lessons specifically designed to build PSTs' understanding of measurement and its connection across the disciplines.

As PSTs prepared to help students learn about the forces of push and pull and changes in motion, their limited understanding of the content was reflected in their instruction designs for students. In the second iteration, we devoted class time for PSTs' guided explorations of Newton's laws of motion. Another exercise that was added in the second iteration required PSTs to document physical science standards from grades K-5 to help them learn the developmental trajectory across elementary grades. Both additions provided PSTs with a broad historical and standardsbased picture of the content. 
Further, in the launch phase of this assignment, PSTs all understood this was their opportunity to hook students and heighten student engagement using the 5E learning cycle model (Bybee et al., 2006), yet virtually all of the PSTs interpreted the hook as separate from the content itself. For our second iteration of the project, both the science and mathematics methods professors were more explicit about the value of content enhancement with students and reinforced an understanding that drawing attention to the content itself, for instance through a discrepant event, is in fact 'the hook.'

\section{Conclusion}

The disconnect between science content coursework and teachers' self-efficacy in communicating content and practices to children (Morrell \& Carroll, 2003) strongly points to the need for both pre-service and in-service teacher professional development to meet the demands of Next Generation Science Standards (NGSS Lead States, 2013) and Common Core (NGA, 2010). Professional development that takes place over an extended period of time and combines content area courses and professional learning communities has the potential to improve teachers' self-efficacy and delivery of reform-based science teaching (Lakshmanan, Heath, Perlmutter, \& Elder, 2011; Sandholtz \& Ringstaff, 2014). Policies that support teachers' continued professional development in presenting STEM instruction are critical to teachers' self-efficacy and in turn student learning. We recognize we have only begun to plant the seeds of STEM integration with the PSTs in this study, and school redesign from elementary through college is needed to blur content area boundaries and provide students with connections to the many everyday issues that require STEM integration.

From our initial attempt to engage our PSTs in an integrated project, we recognized the challenge and importance of providing future and current teachers the opportunity to explore full integration of STEM. Upon reflection we also learned how we could better support our PSTs in developing lessons that focused on content. In particular we adjusted our own instruction to support the PSTs in deepening their content knowledge related to key content standards (e.g., measurement, force and motion). Elementary schools are an excellent venue to begin framing integrated STEM and to impact these understandings. Therefore, it is important for elementary teachers to walk the walk to obscure these boundaries as we work to establish future, and current, teachers' STEM habits of mind.

\section{References}

Ball, D. (1998). Bridging practices: Intertwining content and pedagogy in teaching and learning to teach. Journal of Teacher Education 51(3), 241-247.

Bayer (2010). A Compendium of Best Practice K-12 STEM Education Programs. Retrieved from http://www.bayerus.com/msms/web docs/com pendium.pdf

Bybee, R. W., Taylor, J. A., Gardner, A., Van Scotter, P., Carlson Powell, J., Westbrook, A., \& Landes, N. (2006). The BSCS 5E instructional model: Origins and effectiveness. Colorado Springs, CO: BSCS.

Carrier, S.J., Tugurian, L.P. \& Thomson, M.M. (2013). Elementary science indoors and out: Teachers, time, and testing. Research in Science Education, 43(5), 2059-2083.

Curran, E. A., \& Stokes, M. J. (2003). Learning to control brain activity: A review of the production and control of EEG components for driving brain-computer interface (BCl) systems. Brain and cognition, 51 (3), 326-336.

Feiman-Nemser, S. (2001). From preparation to practice: Designing a continuum to strengthen and sustain teaching. Teachers College Record, 103(6), 1013-1055.

Fink, L. D. (2013). Creating significant learning experiences: An integrated approach to designing college courses. John Wiley \& Sons. 
Lakshmanan, A., Heath, B. P., Perlmutter, A., \& Elder, M. (2011). The impact of science content and professional learning communities on science teaching efficacy and standards-based instruction. Journal of Research in Science Teaching, 48(5), 534-551.

Morrell, P. D., \& Carroll, J. B. (2003). An extended examination of preservice elementary teachers' science teaching self-efficacy. School Science and Mathematics, 103(5), 246-251.

National Academy of Engineering \& National Research Council. (2009). Engineering in K-12 Education. Washington, DC: National Academies Press.

National Council of Teachers of Mathematics. (2000). Principles and standards for school mathematics. Reston, VA: National Council of Teachers of Mathematics.

National Governors Association Center for Best Practices \& Council of Chief State School Officers. (2010). Common Core State Standards. Washington, DC: Authors.

National Research Council. (2000). Inquiry and the national science education standards. Washington, DC: National Academy Press.

National Research Council. (2007). Rising above the gathering storm: Energizing and employing America for a brighter economic future. Washington, DC: National Academy Press.

NGSS Lead States. (2013). Next Generation Science Standards: For States, By States. Washington, DC: The National Academies Press.

Repko, A. F. (2012). Interdisciplinary Research: Process and Theory. Thousand Oaks, CA: SAGE Publications, Inc.

Sandholtz, J. H., \& Ringstaff, C. (2014). Inspiring instructional change in elementary school science: The relationship between enhanced self-efficacy and teacher practices. Journal of Science Teacher Education, 1-23.
Shulman, L. (1986). Those who understand: Knowledge growth in teaching. Educational Researcher, 15(2), 4-14.

Tilgner, P. J. (1990). Avoiding science in the elementary school. Science Education, 74, 421431.

Venville, G., Rennie, L., Wallace, J. (2012). 'Curriculum integration: Challenging the assumption of school science as powerful knowledge'. In B. Fraser, K. Tobin, \& C. McRobbie (Eds.), Second International Handbook of Science Education (Vol. 2, pp. 737749). Dordrecht, The Netherlands: Springer.

Weiss, I.R., Banilower, E.R., McMahon, K.C., \& Smith, P.S. (2001). Report of the 2000 National Survey of Science and Mathematics Education. Chapel Hill, NC: Horizon Research, Inc.

\section{About the Authors}

Sarah J. Carrier is an Associate Professor of Science Education, Teacher Education, and Learning Sciences at NC State University.

Valerie N. Faulkner is an Assistant Professor of Elementary Mathematics Education, Teacher Education, and Learning Sciences at NC State University.

Laura Bottomley serves as the Director of Women in Engineering and Outreach in the College of Engineering at NC State University. 